\title{
A DISCRIMINAÇÃO RACIAL PARTIR DA ASSOCIAÇÃO DA PESSOA HUMANA AO MACACO
}

\section{RACIAL DISCRIMINATION ASSOCIATION FROM THE HUMAN PERSON TO THE MONKEY}

\author{
${ }^{1}$ Daisy Rafaela da Silva
}

${ }^{2}$ Elizabeth Novais Pereira

\section{RESUMO}

Este estudo desenvolvido junto ao Grupo de Pesquisa Direitos Humanos do Programa de Mestrado em Direito do UNISAL, se fez em razão das manifestações nas redes sociais denominadas \#somotodosmacacos e visa apresentar as causas do preconceito racial e associação da pessoa humana negra ao macaco e a continuidade da discriminação racial na atualidade. Faz-se necessário em razão de diversos fatos noticiados pela mídia e também de situações cotidianas não noticiadas, mas que integram a cultura do preconceito que está arraigado desde a colonização.Utilizou-se de análise documental e bibliográfica cujo referencial teórico tem-se Castells, Bauman; Dawkins, Boaventura Sousa Santos e outros. Trata-se de preconceito racial chamar uma pessoa negra de macaco, a ideia preconceituosa é enraizada na cultura ao redor do mundo, no Brasil e em tantos outros países, fatos dentre os quais repercutiu na mídia como \# Somos todos macacos\#. O teatro da vida e os atores foram estudados por cientistas e arqueólogos com suas saídas e entradas na teia humana atemporal. Ao preparar nossa civilização para a ideia da evolução, o quadro é confuso, alguns afirmam que os macacos evoluíram para chegar a raça humana, mas são inverdades, pois cada espécie é uma, descendemos de uma evolução.As pesquisas científicas afirmam são parentes próximos, mas não espécie de grande primata, não somos macacos, somos humanos. Há urgente necessidade de romper-se com a continuidade do preconceito racial e de forma tão ofensiva, nomear os negros como macacos.

Palavras-chave: Preconceito racial, Macacos, Redes sociais

\footnotetext{
${ }^{1}$ Mestrado em Direito pela Universidade Metropolitana de Santos, UNIMES. São Paulo. SP, Brasil.

E-mail: indexlaw.ojs@hotmail.com

${ }^{2}$ Mestrado em Direito do UNISAL de Lorena, São Paulo. SP, Brasil. E-mail: indexlaw.ojs@ @otmail.com
} 


\begin{abstract}
This study developed by the research group "Human Rights" Master's Program in Law UNISAL, was made because of the demonstrations on social networks called "\#somotodosmacacos" and aims to present the causes of racial prejudice and association of black to the human person monkey and the continuity of racial discrimination today. It is necessary due to several facts reported by the media and also of everyday situations not reported, but part of the culture of prejudice that is ingrained from colonização.Utilizou up of documentary and bibliographical analysis whose theoretical framework has Castells, Bauman; Dawkins, Boaventura Sousa Santos and outros.Trata is racial prejudice call a black person "monkey", the prejudiced idea is rooted in the culture around the world, in Brazil and many other countries, facts of which reverberated in the media as \# \# We are all monkeys. The theater of life and the actors were studied by scientists and archaeologists with their exits and entries in the timeless human web. In preparing our civilization to the idea of \&\#8203; \&\#8203; evolution, the picture is confused, some claim that apes evolved to get the human race, but they are untrue, as each species is one, descended from a evolução. As scientific research claim are close relatives, but kind of great ape, we are not monkeys, we are human. There is an urgent need to break with the continuity of racial prejudice and so offensive form, appoint blacks as monkeys.
\end{abstract}

Keywords/Palabras-claves/Mots-clés: Racial prejudice, Monkeys, Social networks

\title{
INTRODUÇÃO
}

Neste século XXI ainda persiste a questão sobre qual a origem do homem. O homem deriva de alguma espécie? Há uma linha evolutiva que relaciona homem ao macaco? Quais são as evidências da evolução humana dar-se a partir dos primatas? Há justificativa para a intolerância, o desrespeito à pessoa humana negra?

O que se pretende com este estudo é encontrar as razões sobre o preconceito/ discriminação racial em chamar um negro de "macaco", as origens dessa ideia preconceituosa enraizada na cultura ao redor do mundo, e no Brasil. Tendo como propulsor destas questões, o movimento que repercutiu nas redes sociais em 2014, denominado "\#Somos todos macacos". 
Partindo-se da associação humano=macaco, fez-se necessário pesquisas dentre os quais destacam-se o Charles Darwin, Richard Dawkins, Santo Agostinho e a visão criacionista da criação dos homem e da origem das espéciesre, dentre outros autores.

\section{Humano e Macaco: relação e aproximações}

Ao tratarmos do humano, buscou-se a definição de homem na natureza e no senso comum, segundo Abbagnano (1990, p. 512),

As definições do primeiro grupo são de natureza religiosa e teológica, mas também podem ser encontradas em doutrinas que nada têm de religioso e teológico. Qualquer definição desse gênero baseia-se na expressão do Gênese. "E Deus disse: façamos o H. à nossa imagem e semelhança" (Gên., I, 26). Esta ex- pressão servia freqüentemente de ponto de partida para especulações sobre a alma, especialmente sobre suas divisões (v. ALMA): na realidade, ela é a definição explícita do H. e, como tal, foi considerada pelos teólogos da Reforma. Por outro lado, Aristóteles, ao tratar da vida contemplativa, falou de um "elemento divino" do H., que, na mesma medida em que excede no todo que constitui o H., torna o $\mathrm{H}$. virtuoso e bemaventurado (Et. nic, X, 6, 1177b 26). Mas esse tipo de definição do H. na tradição filosófica teve como inspiração constante a Bí- blia. Viram o H. como imagem de Deus: CALVINO (Institutie, I, 15, 8) e ZWÍNGUO (Deutsche Schrifter, I, 56). Através das ricas amplificações de JACOB BOEHME (cf., p. ex., Aurora oder die Morgenrôthe im Aufgang, VI, I), esse conceito passou para a filosofia romântica alemã. Spinoza dizia que "a essência do H. é constituída por certas modificações dos atributos de Deus" (Et., II, 10. Corol.). Nas lições sobre a Destinação do douto, em 1794, Fichte apontava como tarefa do H. adequar-se à unidade e à imutabilida- de do Eu absoluto, segundo a máxima "age de tal forma que possas considerar a máxima da tua vontade uma lei eterna para ti" (Über die Bestimmung des Gelebrten, 1794, I). Mas o Eu absoluto é o princípio ou a substância do H., e sua unidade e sua imutabilidade são apenas a unidade e a imutabilidade de Deus, de tal for- ma que a melhor maneira de expressar a dou- trina de Fichte a esse respeito é que o H., em seu princípio ideal, é Deus e deve esforçar-se por tornar-se tal. Analogamente, para Hegel o H. é essencialmente Espírito e o Espírito é Deus. Diz: "Conquanto considerado finito por si mesmo, o H. é também imagem de Deus e fonte da infinidade em si mesmo, pois é o fim de si mesmo e tem em si mesmo o valor infinito e a destinação para a eternidade" (Philosophie der Geschichte, ed. Gloekner, p. 427). Hegel define cristianismo como a posição de "unida- de do H. e de Deus" (Ibid., p. 416). Nessas definições de H., a relação do H. com Deus é vista de forma positiva. 
A relação entre o humano e os animais, e no caso em tela o macaco, tende a ser filosófica até mesmo devido ao fato dos pré-socráticos se preocuparem com as causas primeiras. Sócrates acreditava na imortalidade da alma e que ele próprio recebeu em sua vida uma missão do deus Apolo para que ele defendesse o "Conhece-te a Ti Mesmo".

Dessa forma, filosofar torna-se um incessante exame de si e dos outros colocando o homem e os seus problemas como centro dos interesses da filosofia. Pode ser vista de modo negativo ou invertido, permanecendo substancial distinguindo-nos dos animais por sermos racionais.

A fim de uma convivência pacífica, foi criada um sistema jurídico, com normas escritas, com fundamentos na moral, atribuindo-se direitos e deveres, o que já nos difere dos animais irracionais. Criamos leis para nosso próprio benefício e nossa sobrevivência e contra nós mesmos e nossos semelhantes, não apenas destruímos outros animais como a nós mesmos, por guerras, por questões religiosas e ideologias. Somos humanos demasiadamente desumanos.

Os humanos são animais bípedes, racionais, incomuns, imagináveis que mudaram, evoluíram ao redor do mundo, esse ser complexo e fruto de inúmeros estudos tanto no campo da filosofia como nas demais ciências. O ser humano dotado de sentimentos e alma, determinados que hora nos comove hora nos assusta, pois ainda perguntamos: Seria o homem capaz de tal fato? Bons ou ruins, ainda nos deixam perplexos seus feitos e realizações.

Fundada nas teorias de Dawkins (2012, p. 40) descendemos do 185 milionésimo avô era um peixe e peixe da 185 milionésima avó, onde não poderiam ter se reproduzido e os seres humanos existirem. Quais aparências tiveram nossos ancestrais?

Segundo Dawkins, apesar de não termos fósseis para nos relatar tal fato, todos os seres vivos são parentes e parentes uns dos outros (como o homem do chimpanzé, o rato e o camundongo), basta fazermos uma comparação do DNA, que é a informação genética de todos seres vivos em que cada uma de sua células e todos esses genes já foram examinados com letras do alfabeto A, T, C e G.

Todo código genético é como se fosse um dicionário com base nos genes traduzidos, é o mesmo constatado pelo cientistas os mesmos, por fim chegou-se a conclusão que todos somos parentes. Dawkins (2012, p. 52) diz que nossa àrvore filogenética faz com que seja afirmado que inclui o macacos e os chimpanzés, mas também os camundongos, búfalos, dentes de leão, águias entre outros, todos são nossos parentes e se tem certeza que é verdade. 


\section{A origem do Humano: mitos e verdade}

O mito judaico, por assim dizer no livro sagrado do judaísmo, o mundo foi criado em seis dias, no quinto, criou os peixes, as baleias e todos seres marinhos, além das aves. No sexto dia criou o restante dos animais terrestres inclusive o homem. Criou, pois, Deus os monstros marinhos, e todos os seres viventes que se arrastaram, os quais as águas produziram abundantemente segundo as suas espécies; e fez "os animais selvagens segundo suas espécies" e "todo réptil que se arrasta sobre a terra [...] segundo suas espécies". DAWKINS (2012, p. 57)

Isso nos remete a um conceito bíblico, descrito no livro de Gênesis, na alusão, Deus julgou o primeiro homem que necessitava de um companheira, Adão e Eva.

Em outro mitos, dos povos aborígenes do sudeste da Austrália, o Sol nasceu de uma ave pernalta e incendiou uma pilha de lenha que estava nas alturas, o Deus do céu notou a luz e que era necessário que fossem colocados lenhas toda noite para iluminar o outro dia. $\mathrm{Na}$ África ocidental, em tribos da Nigéria como em outras partes, o Sol e a Lua, a Lua como feminina e o Sol masculino, um marido do outro, filhos de deus supremo, já na região japonesa, o Sol é a deusa Amaterasu e a Lua é seu irmão Ogetsuno. Na América do Sul, antes de chegar os povos "colonizadores" espanhóis no século XVI, o Sol e a Lua eram os ancestrais, em algumas civilizações, como o mito asteca, há cinco sóis em quatro mundos cada qual com seu sol. Os astecas acreditavam que tinham de sacrificar vítimas humanas para apaziguar o Sol, do contrário apareceria toda manhã, com a chegada dos espanhóis foram sacrificados 20 mil e 80 mil pessoas em oferendas aos deuses.

Os egípcios adoravam o Sol, uma das suas principais divindades era $\mathrm{Ra}$, o deus sol, toda noite se curvava em torno da terra e engolia o Sol e na manhã seguinte devolvia à luz novamente. Os gregos descreviam o Sol como deuses em carruagensm Hélio era o deus Sol dos gregos.

"O Sol é uma estrela igual a muitas outras, ele nos aquece e pode danificar nossa pele e olhos." DAWKINS (2014, p. 124). O mito africano do Congo, os boshogongos, não havia terra, somente escuridão e um deus vomitou o sol, secando boa parte das àguas e ainda passando mal vomitou as estrelas, ao animais e as pessoas, imagine contar a uma criança hoje que fomos vomitados? O que ela iria dizer? 
$\mathrm{Na}$ China um personagem conhecido como Pan $\mathrm{Gu}$, um gigante peludo com cabeça de cão, no princípio não havia distinção entre o céu e a terra era tudo massa gosmenta, e ele quando acordou quis escapar pegou um machado e quebrou a casca do ovo e que ao quebrar afundou e tudo se tornou terra, em 18 mil anos que Pan Gu dormiu, o céu e a terra incharam e é o que é hoje.

Afinal temos os cientistas que no século XX e XXI são questionados e os menos instruídos alegam que há apenas "teorias". De um lado Dawkins e suas provocações nas questões criacionistas e evolucionistas, cujo palco de discussões se dá nas Universidades dos Estados Unidos pelo número extenso de protestantes. Steven Hawking nos apresentou a mão de Deus, se diz ateu mas, surge como as civilizações passadas, com o nome Deus.

Antes de compreendermos a ciência, o lógico acreditava-se que Deus criou o Universo, mas, agora, a ciência oferece uma explicação mais convincente (...) Não há nenhum Deus. Sou ateu. A religião crê em milagres, mas esses não são compatíveis com a ciência”. A respeito disso, o cientista também se manifestou, confiante de que o homem, cedo ou tarde, vai entender a origem e a estrutura do universo: "Na verdade, agora mesmo, já estamos próximos de alcançar esse objetivo. Na minha opinião, não há nenhum aspecto da realidade fora do alcance da mente humana" (DAWKINS).

As ideias que surgem e ainda continuam a surgir são soluções que remete esse artigo a apresentar que afinal, o que somos e de onde viemos?Surgem histórias e repeti-las, algumas mirabolantes ou mito antigo, seria alguma delas verdade? Esses mitos falam a verdade, ou Santo Agostinho está certo ao afirmar que somos criacionistas que os seres humanos "são seres de criação", cabe a cada um fazer sua interpretação, percebemos que há uma convicção puramente em modelos que se dizem corretos, alguns iluminados por Deus, outros pelo Sol, que em boa parte do Oriente, as questões católicas não influenciam tanto nas mudanças do pensamento. Mas é forte no ocidente a visão de fé, da descendência humana de Adão e Eva.

E ainda ver nitidamente os preconceitos em colocarmos em camisetas a imagem da evolução de um macaco de cócoras até o homo sapiens sapiens, uma visão preconceituosa, de que

somos descendentes do macaco, estando o negro na linha da exclusão, enraigado nas entranhas da humanidade.

\section{Evidências científicas: evolução e parentesco}


Devido à ligação dos seres humanos com os pensamentos dos povos antigos nem sempre ligados as ideias religiosas como podemos citar os filósofos que não possuíam essa idéia de um Deus no céu e os humanos na terra, até mesmo pelo fato de haver controvérsias a respeito das origens dos seres vivos e as relações de parentesco com suas origens comuns.

Como reconstituir cenas e atores dos nossos antepassados? Segundo Dawkins(2009, p. 30) tem a arqueologia, o estudo dos vestígios como pontas de flecha, fragmentos de cerâmica, monturos de conchas, estatuetas, ossos e dentes e os fósseis, resistiram ao tempo. Todos estudados por cientistas e arqueólogos com suas saídas e entradas na teia humana atemporal. Nossa história é evolutiva e todos os seres vivos são primos.

O primeiro fóssil descoberto da raça humana segundo Dawkins (2009 p. 55) foi na caverna de Dordonha na França. O Homo sapiens, há cerca de 40 mil anos, nossos ancestrais eram iguais aos que viveram depois; as ferramentas e seus artefatos não mudaram por um milhão de anos e os que chegaram às mãos dos estudiosos são ferramentas e armas.O que os estudiosos discutem é que o salto da evolução humana ocorre lentamente, mas de maneira evolutiva, pois na descoberta do Homo sapiens não possuíam pinturas, estatuetas, esculturas e ao dar um salto a evolução da espécie humana produz instrumentos musicais como as flautas de osso e os povos da Caverna de Lascaux, criaram obras impressionantes. E hoje, pode-se observar a cultura moderna, a tecnologia, as armas, os aviões, os carros e a rede mundial de computadores, os celulares, enfim uma miríade de aparatos que podem se dizer decorrentes das evoluções dos humanos, e como não observar a evolução na linguagem, sendo muito fácil hoje nos comunicarmos em tempo real, evoluímos ou não?

Segundo Dawkins (2009 p. 85) ao existir dois tipos de sangue A e B, ambos possuem diferentes imunidades a diferentes doenças, um é suscetível e o outro imune, esse poliformismo podem ser estáveis. Nosso poliformismo A e BO estão nos chimpanzés sendo mais plausível que os humanos e os chimpanzés herdaram dos seus ancestrais comuns. E sua conclusão surpreendente é que, para genes específicos você é mais aproximadamente aparentado com alguns chimpanzés do que com alguns humanos.

Há duas espécies que existem e que é sabido, somos descendentes de Neandhertais? Ou eles cruzaram com o Homo sapiens sapiens para que possamos existir? Essas duas espécies 
coexistiram na Europa por muito tempo, sem dúvida os estudiosos acreditam que ambas se contactara, e que os Homens de Neandertal provavelmente morreram sem deixar descendentes e quaisquer identidade. Quando falar em descendência evolutiva refere-se a genes ancestrais, e não ancestrais genealógicos.

Para muitos paleontólogos, o cérebro grande é a característica distintiva do nosso gênero, os Habilinos com cerca de mais ou menos 10 milhões de anos apareceu, através da evolução do Dryopitheais, o gênero Pongidae (Orangotango e Gibão) a 8 milhões outro gênero surgiu, os Hominidaes que engloba os chimpanzés, gorilas e homens. E somente a 4 milhões de anos atrás, surgiu o subgênero homo, que foi descoberto por Raymond Dart em 1924, através de um crânio que apresentava características do crânio humano com 600 $\mathrm{cm}^{3}$ o qual se deu o nome de Australopitheco .

Dawkins (2009 p. 115) chama de bobagem os textos oferecidos para o público leigo na alegação de descobrir o "primeiro" ancestral humano, sugere ao perguntar qual o primeiro ancestral humano a andar habitualmente entre duas pernas e qual a criatura que foi nosso ancestral. A pergunta que todos fazem é de onde viemos, para onde vamos? Nos últimos 300 anos na história da humanidade, as ciências, a cosmologia, a física, a arqueologia, a biologia, entre outras estudam a partir de grandes filósofos. E a cerca de 2.800 anos observa-se a preocupação em explicar as causas e o princípio de tudo e de todas as coisas, dando nomes a cada movimento da natureza, como o fogo, a água o ar entre outros, a origem do cosmos.

Dawkins (2009 p.116) segue ainda dizendo que na medida em que a terra entrega aos estudiosos mais fósseis, fica claro que a história dos hominídeos na África, muitos ancestrais do homem foram na verdade nossos primos, como os Australopithecus, (ou Paranthropus) robustus, Australopithecus (ou Paranthropus ou Zijanthropus) boisei e Australopithecus (ou Paranthropus) aethiopicus. Exemplo da Sra. Ples descoberta como Australopithecus grácil encontrada exposta no Museu Tranvaal de Pretória, e a Lucy de 3,2 milhões de anos também Autralopithecus grácil é uma forte concorrente a ancestral humana, ao todo foram encontrados 13 com idade de 3 e 4 milhões de anos na África Oriental.

Uma teoria interessante é a libertação das mãos (bipedalismo) talvez para carregar os alimentos, para se alimentar, para dançar, lutar. Para Dawkins (2009 p. 133) o chimpanzé se parece mais com os grandes primatas do que com os humanos. Ocorre que as mudanças 
da evolução na linha humana de descendência do ancestral comum do que nas linhas dos chimpanzés. Não podemos supor como fazem muitos leigos, que nossos ancestrais foram chimpanzés, sendo o termo "elo perdido" um indutor a esse equívoco.

Dawkins (2009 p. 133) contesta e diz que é ilusão, que somos parentes mais próximos dos bonobos do que dos chimpanzés comuns. Nosso parentesco com as duas espécies é exatamente igual. Bonobos e humanos compartilham 98,7\% do mesmo mapa genético, o mesmo percentual compartilhado pelos humanos com os chimpanzés, de acordo com o estudo. Os dois macacos têm uma relação muito mais estreita entre si - compartilham 99,6\% de seus genomas - disse o principal autor do artigo, Kay Prufer, geneticista do Instituto Max Planck, na Alemanha. "Os seres humanos são um pouco como um mosaico dos genomas de bonobos e chimpanzés."Segue ainda o autor alegando que os humanos são primos tão próximos dos orangotangos, quanto os chimpanzés, bonobos e gorilas, são igualmente aparentados conosco porque estão ligados a nós por intermédio do mesmo ancestral comum.

\section{Aspectos científicos e religiosos}

A teoria da evolução é na verdade um fato incontestável como qualquer outra ciência, devido ao avanço tecnológico de máquinas que calculam com precisão certas evidências. Desde os estudos de Darwin que no ano de 2009 completou 200 anos e o livro A origem das espécies 150 anos. Diante dos estudos de Darwin fica provada a evolução e o estudo preciso das origens das espécies por ele estudado para muitos cientistas até mesmo para o filósofo Aristóteles, que foi o primeiro cientista que procurou classificar os seres vivos. Ele dividia os seres vivos em dois grandes grupos: animais e vegetais. Após a morte do sábio grego os estudos sobre os seres vivos ficaram praticamente esquecidos e só foram retomados a partir do século XIV, com o Renascimento. Nessa época os artistas passaram a se interessar pela anatomia do homem e dos animais. A classificação dos seres vivos passou a ser uma grande preocupação dos naturalistas dessa época .

Obras de biologia escritas por Aristóteles: História dos Animais, Partes dos Animais, Movimento dos Animais, Progressão dos Animais, Geração dos Animais, Obras de Aristóteles sobre a METAFÍSICA. 
O homem da Grécia buscava respostas para seus questionamentos, Aristóteles recebia de Alexandre Magno que percorreu $6.500 \mathrm{~km}$ com sua tropa e enviava a Aristóteles mostras de plantas e espécies de lugar por ele explorado, não há nenhum relato de Alexandre ter ficado frente a frente com um primata, tendo em vista que o mesmo não chegou como rege a história até África. Como em cada região o solo se comporta e fornecem espécies diversificadas,

cultura entre outros aspectos pode-se dizer que Aristóteles foi o primeiro cientista a dar início aos estudos de outras espécies, as obras citadas acima foram estudos de amplo aspecto sobre as espécies, com o passar dos anos o avanço tecnológico, as pesquisas evoluíram e milhares de novos seres (principalmente microorganismos) foram descobertos. Atualmente os seres vivos são agrupados em cinco grandes grupos, conhecidos como reinos: Monera, Protista, Fungo, Vegetal e Animal.

A ciência criou meios para que alternativas fossem oferecidas, na saúde, vacinas, remédios, há controvérsias que afirma que o homem cria meios de distribuição

Alguns intelectuais e cientistas se acham no direito de negar e obter para si uma crença pessoal sobre qualquer evidência dos seres humanos evoluímos e que devem ser respeitados nos limites éticos, bioéticas e Direitos Humanos. Dawkins afirma: "Provavelmente pensam que Deus deu a partida no Universo e solenizou seu nascimento com um harmonioso conjunto de leis e constantes físicas calculadas para atender algum propósito insondável no qual nós por fim teríamos um papel. Porém, relutantes alguns, satisfeitos outros, religiosos e religiosos ponderados e racionais aceitaram as evidencias da evolução.’(DAWKINS, 2009, p.16)

Santo Agostinho fica indeciso entre o criacionismo e o traducionismo, isto é, se a alma é criada diretamente por Deus, ou provém da alma dos pais. Certo é que a alma é imortal, pela sua simplicidade. Agostinho, pois, distingue, platonicamente, a alma em vegetativa, sensitiva e intelectiva, mas afirma que elas são fundidas em uma substância humana. A inteligência é divina em intelecto intuitivo e razão discursiva; e é atribuída a primazia à vontade. No homem a vontade é amor, no animal é instinto, nos seres inferiores cegos apetite. Cientistas e criacionistas interpretam o termo "teoria" e duas acepções bem distintas segundo Dawkins; 
A evolução é um fato: Além de qualquer dúvida razoável, além de qualquer dúvida séria, além da dúvida sã, bem informada, inteligente, além de qualquer dúvida, a evolução é um fato.(DAWKINS,2009, p. 18)

Filósofos alegam que os cientistas não podem provar coisa alguma em ciência. Segundo Dawkins (2009, p. 30) citando Mayer, a razão porque um Darwin demorou tão despropositadamente a surgir em cena foi que nós todos quer por influência dos gregos, quer por alguma razão - temos o essencialismo gravado e nosso DNA mental. Segue ainda o autor que diz que Platão via um coelho como um coelho, e possuía um tabu interno sendo essencialista, inventada em 1945 por Mayer ,portanto, Darwin não estava mais disponível.

4A questão é que Darwin surgiu no século XIX com outra visão, anti-essencialista embora na época compunha de um ponto de vista essencialista da evolução a população, cada pessoa, animal se mistura em uma cadeia, animais intermediários que ligam, por exemplo um coelho a um leopardo. Uma espécie moderna não evolui para uma espécie moderna, elas possuem ancestrais em comum: são primas.

Dawkins (2009, p.30) dá uma resposta inquietante. "Mas se os humanos evoluíram dos chimpanzés, como é que ainda existem chimpanzés no mundo?”. O autor segue afirmando que há ancestrais na mesma linha de ramificação no sentido a evolução, um animal se posiciona na curva de $180^{\circ}$ graus é o ancestral mais antigo, não somente de coelhos e leopardos, e sim uma grande fração de mamíferos modernos.

Em 1949 Konrad Lorenz, etologista austríaco, ganhou o prêmio Nobel da Paz por explicar rigorosamente sobre o reservatório gênico da raça ou espécie (gene pool) conhecida por síntese "neo darwiniana", onde nem Darwin sabia sobre esse reservatório gênico. Mendel, o pai da genética, explicou que ao herdarmos os genes dos nossos pais, eles não se misturam e sim são embaralhados, os genes não se fundem e sim se embaralham como cartas que permanecem juntas por várias gerações, o óvulo feminino com o esperma masculino são os mesmos genes específicos provém de um, apenas um dos quatro avós e de apenas um dos oito bisavós.

O DNA mostra que somos todos primos, pois não foram encontrados fósseis para nos dizer como era nossos ancestrais, sequer os mais remotos, isso sem dúvida demonstra que são parentes e parentes uns dos outros. RICHARD DAWKINS (2012, p. 50) 
A teoria usada aqui por Dawkins remete ao direcionamento a um Deus criador de todos os seres vivos na terra. No livro de Gênesis, revela que o homem fabricado por ele com barro, havia insuflado seu espírito no mesmo, e colocado como rei da criação no jardim do Éden e extraído uma de suas costelas gerou Eva sua companheira, etc.Na bíblia de Jerusalém está escrito:“Deus disse: Que a terra produza seres vivos segunda sua espécie: animais domésticos, répteis e feras segundo sua espécie" e assim se fez. A BÍBLIA DE JERUSALÉM (1973, cap. 1, versículo 24)

\footnotetext{
"Deus disse: Façamos o homem à nossa imagem, como nossa semelhança e que eles dominem sobre os peixes do mar.” (1973, cap. 1, versículo 26)

"Deus criou o homem à sua imagem à imagem de Deus ele criou homem e mulher ele os criou.” (1973, cap.1, versículo 27)
}

A Bíblia Sagrada, que apresenta a regra de conduta e fé, a Palavra de Deus e o Livro de Sabedoria dos cristãos, de todo nosso vasto mundo é, sem dúvida, o livro mais lido, comentado, interpretado, combatido e perseguido de toda a história da humanidade. A Bíblia, cujo nome provém do termo biblia, o plural de biblio, i.e., livro, tanto em grego koiné quanto em moderno, está presente em todos os continentes, em mais de 350 países do mundo. O número de leitores ativos e passivos deste livro singular alcança a fenomenal marca de 4 bilhões de pessoas, quase dois terços da população mundial; seus escritos e poesias já foram traduzidos para todas as línguas oficiais e quase 8.000 dialetos e línguas não-oficiais já dispõem de toda ou parte da Escritura Sagrada. Por ter tais características, a Bíblia compõe, então, a antologia de obras poético-históricas mais influenciadora do mundo. Civilizações ocidentais inteiras são baseadas em seus escritos: preceitos de ética e moral, fundamentos de direito e justiça, a organização social e familiar são inspiradas na Bíblia e aplicadas à Civilização Cristã Ocidental .

Einstein que era um físico que considerado ateu por muitos por ser um cientista, criou a Teoria da Relatividade que revolucionou o pensamento da humanidade sobre o tempo e o espaço, um físico genial, cérebro brilhante. Pai da ciência moderna e um entusiasta dos direitos humanos, Einstein deixava claro que a ciência e a religião eram complementares. Há uma frase em que ele diz: “A ciência sem a religião é manca, a religião sem a ciência é cega." 
A religião segundo o próprio Einstein disse: "Ter a sensação de que por trás de tudo que pode ser vivido há alguma coisa que nossa mente não consegue captar e cuja beleza e sublimidade só nos atingem indiretamente, na forma de um débil reflexo, isso é religiosidade. Nesse sentido, sou religioso."

Com essas declarações ambas opostas, de um cientista ateu como Dawkins e Einstein, outro cientista e que não afastava as possíveis forças existentes na nossa natureza a ciência nada mais é que racional e a religião o mito, a superstição. É preciso acreditar em algo porque só a sua existência não basta. O cristianismo foi criado após o nascimento de Jesus e disseminada pelo apóstolo Paulo, que levou o cristianismo em toda Grécia e Ásia Menor, atualmente é um terço da população mundial é cristã, o equivalente a 2,18 milhões de pessoas, revela hoje um mega-estudo do centro de investigação norte-americano Pew, realçando que os cristãos são o primeiro grupo religioso, à frente dos muçulmanos .

"O local próprio para o estudo das crenças religiosas é numa igreja ou no templo, em casa, ou num curso sobre religiões comparadas, mas não numa aula de biologia Não há lugar no nosso mundo para uma ideologia que procura mentes fechadas, força à

obediência, e retorna o mundo a um paraíso que nunca existiu. Os estudantes devem aprender que o universo pode ser confrontado e entendido, que ideias e autoridades devem ser questionadas, que uma mente aberta é uma coisa boa. A educação não existe para confirmar a superstição das pessoas, e as crianças não aprendem a pensar quando elas são alimentadas apenas com dogmas ." Tim Berra, Evolução e o Mito do Criacionismo.

O criacionismo é o produto mais recente de um desenvolvimento histórico denominado como a evolução do anti-evolucionismo, enfatiza a vida na terra há menos de dez mil anos, os humanos e os macacos não teriam nenhum ancestral comum, e as camadas geológicas surgiram devido ao dilúvio. Alguns crentes fiéis conciliaram sua fé com a evolução e outros defensores de Darwin.

Nos anos vinte do século $\mathrm{XX}$, ocorreu uma cruzada contra a teoria da evolução os teístas sofreram dificuldades com os adeptos de suas igrejas onde três estados americanos proibiram as escolas públicas de se ocuparem com a teoria da evolução. Sendo retirado dos livros e os autores e editoras de circulação que envolvesse qualquer assunto sobre a teoria da evolução. 
Os modernos criacionistas já consideram os fósseis consequiência do dilúvio no tempo de Noé, teoria de um adventista do sétimo dia.

Com a decodificação da estrutura da função do DNA, em 1954, a biologia cresceu no mundo acadêmico, já em 1957 os russos enviaram ao espaço o Sputnik não tripulado em 1961 avançaram mais que os americanos os mesmos ficaram atrasados no campo científico e da técnica.

O criacionismo atual surgiu em 1970 da qual uma lei em Arkansas obrigou a teoria da criação e a teoria da evolução ser ministrada pelos professores de biologia. $\mathrm{O}$ reverso ao desenvolvimento pós-moderno ao da Idade Média ou anterior a isso é um fato pois, parece que os termo evolução é uma questão discutida e rejeitada.

Para Drees (2007, p.62) o criacionismo, por conseguinte, significa rejeição da ciência, e com isto rejeição de dons divinos, sejam os dons da curiosidade e da inteligência humana, sejam também os dons do mundo, com suas regularidades e causalidades. Uma fé assim rejeita a criação tal como a conhecemos através das ciências naturais; Deus está em conflito com a natureza. Para surpresa geral, o papa João Paulo II, em 1992, que, após exatamente 350 anos da morte de Galileu, desculpou-se pelos erros cometidos pelos cardeais inquisidores e reconheceu que o cientista Pisano estava certo.Falou o papa sobretudo dos males que resultam da separação entre ciência e fé. Galileu não foi mencionado, mas João Paulo II falou das

várias confrontações já ocorridas entre os cientistas e os teólogos e disse que se deve lamentar "O peso destes famosos conflitos, nascidos da interferência de entidades religiosas no processo evolutivo do conhecimento científico. A Igreja recorda-se disto com amargura, porque hoje nos damos conta dos erros."

Segue ainda João Paulo II que o intercâmbio entre a ciência e a teologia beneficiará a ambas, visto que "a ciência pode purificar a religião do erro e da superstição" e "a religião pode purificar a ciência da idolatria e dos falsos absolutos". E das deficiências destes modos de proceder. Podemos hoje afirmar que eles foram superados: graças à força de persuasão da ciência, e graças, sobretudo ao trabalho de uma teologia científica que, aprofundando a compreensão da fé, a libertou dos condicionamentos do tempo. 
Indo além desta tomada de posição do Concílio, desejo que teólogos, sábios e historiadores, animados por espírito de sincera colaboração, aprofundem o exame do caso de Galileu e, num reconhecimento leal dos erros de qualquer lado que tenham vindo, façam desaparecer as desconfianças que este assunto opõe ainda, em muitos espíritos, a uma concórdia frutuosa entre ciência e fé, entre a Igreja e o mundo. Dou todo o meu apoio a esta tarefa, que poderá honrar a verdade da fé e da ciência, e abrir a porta a futuras colaborações .

O Papa João Paulo II na Carta Encíclica Fides Et Ratio (Fé e Razão) escrita em 15 de setembro de 1998 trata da verdade, sendo a questão fundamental da vida e história da humanidade, pediu a fé na filosofia entre a cultura, raça ou religião, pois o homem sempre procura uma verdade última mas nunca encontra as respostas, é assim na religião e assim na ciência, mas ambas causando um ceticismo generalizado.

Dawkins em "Deus é um delírio" expõe (2007, p.224) que o arqueólogo Colin Renfrew, de Cambridge, sugere que o cristianismo sobreviveu devido a uma forma de seleção de grupo, alimentava a idéia de lealdade e de amor em um grupo e até hoje observamos o comportamento de alguns grupos cristãos, em que prega-se um Deus puro, humano, amoroso, fiel e passa a ser deus um ser humano e não um ser supremo, criador, inefável, mas humano porque ele simplesmente é, e não possui características dadas.

Para o cristianismo, a vida foi dada e criada por deus, espírito imortal não sujeito da vida biológica, pela alma o ser humano é ordenado por um destino espiritual e superior, sendo uma convicção geral, até o surgimento da teoria da evolução, quando falamos teoria no dicionário, Dawkins (2009, p. 19) encontra duas definição:

Teoria, acepção 1: Conjunto ou sistema de ideias ou afirmações apresentado como explicação ou justificativa de um grupo de fatos ou fenômenos...Teoria, acepção 2: Hipótese proposta como explicação; por conseguinte, mera hipótese, especulação, conjectura; idéia ou conjunto de ideias a respeito de alguma coisa...

\section{5.\#Somos todos macacos\#: Discriminação racial = Preconceito racial}

O raciocínio e a meditação sobre os atos de discriminação racial são importantes nesse estudo pois tratar o outro (igual) sob aspectos de ser "diferente" nos leva a negar o ser 
humano, viver em sociedade com dignidade e não sofrer qualquer tipo de constrangimento. Pautados nos Direitos Humanos, consta na nossa Constituição Federal de 1988 o princípio de que todos são iguais perante a lei, não podendo haver distinção de nenhuma modalidade entre brasileiros, seja nas ruas, nos estabelecimentos, nas escolas, e nos estádios de futebol onde o uso da palavra "macaco" surgiu como forte manifestação racial contra os negros. O que levou o homem contemporâneo apesar do avanço tecnológico e social a continuar a associar, discriminando, e ofendendo a dignidade da pessoa humana negra com um macaco?

Para Dawkins (2009 p. 142) a questão da discriminação vem do fato de que os primeiros exploradores brancos da África consideravam os chimpanzés e gorilas parentes próximos apenas dos humanos negros e não de si mesmo. Os grandes primatas foram vistos como humanos negros. Orangotango em malaio significa "homem das florestas". Para ilustrar a tragédia deste "homem" em extinção os grandes primatas são vistos como "grandes primatas humanos que caíram em desgraça".

Ao preparar nossa civilização para a ideia da evolução, há a falta de informação a em todos os níveis de ensino, o quadro é confuso, alguns afirmam que os macacos evoluíram para chegar a raça humana. Inverdades, pois cada espécie é uma, descendemos de uma evolução, as pesquisas científicas afirmam que somos parentes próximos, mas não somos espécie de grande primata, não somos macacos, somos humanos!

Mas temos com esses animais, isto sim, um antepassado em comum, que viveu há mais de 6 milhões de anos em algum lugar da África. Se pudéssemos ressuscitá-lo, a criatura seguramente se pareceria com um macaco - afinal, ela também foi uma espécie de primata. Mas teria detalhes anatômicos que não existem em nenhum animal que conhecemos hoje. O conceito equivocado de que "viemos dos macacos" tem origem na ideia mais equivocada

ainda de que a evolução é um processo linear, no qual novas espécies vão substituindo outras. Ora, os humanos não substituíram chimpanzés, gorilas ou orangotangos. Esses animais estão por aí, dividindo o planeta conosco. O que ocorreu é que nosso ancestral comum - aquele, que viveu em solo africano há pelo menos 6 milhões de anos - acabou dando origem a duas linhagens distintas (provavelmente em virtude de mudanças climáticas e outros fatores ambientais). Uma delas seguiu a trilha evolutiva que resultaria 
nos macacos de hoje. A outra, contudo, percorreu um caminho diferente, até chegar ao homem moderno. Ou seja: somos primatas, sim, tanto quanto os chimpanzés. Até nossos genes são quase os mesmos, $90 \%$ iguais. Mas isso não quer dizer que sejamos a evolução da Chita! Tivemos um antepassado em comum.

O apresentador Danilo Gentili criou um mal estar ao dizer a seguinte frase: "King Kong, um macaco que, depois que vai para a cidade e fica famoso, pega uma loira. Quem ele acha que é? Jogador de futebol?" Ao falar do filme de King Kong automaticamente fez uma piada associando o macaco ao ser humano e a jogador de futebol. As entidades e grupos afro-brasileiros repudiaram tal piada e por meio de twitter, o humorista pergunta porque não se pode chamar um negro de macaco, não deve-se uma explicação do porque, mas como a mesma fere os sentimentos de algumas pessoas.

Outro fato ocorrido, foi o do jogador de futebol Daniel Alves, no jogo entre Villareal e Barcelona pelo Campeonato Espanhol, momento em que um torcedor atirou no jogador uma banana e o mesmo simplesmente a comeu, gerando uma onda de manifestações e apoio ao jogador. Equivocadamente o jogador Neymar e outras celebridades postaram em redes sociais suas fotos segurando uma banana e dizendo: "\#Somos todos macacos"

Outro fato lamentável ocorrido em um jogo de futebol que gerou polêmica racista foi novamente com o goleiro do Santos, conhecido como Aranha, em uma partida de futebol, ele estava no gol e começou a escutar chamá-lo de "preto fedido" "cambada de preto", a imagem revoltou a todos os expectadores. Principalmente nas imagens que chocou foi o fato de algumas pessoas que acham que ele exagerou, como se manifestou Pelé, que disse ter ouvido isso ao longo de sua carreira.Fatos que nos levam a contestar, se ao mesmo tempo ao postarmos fotos segurando uma banana leva-nos a mais racismo e preconceito na sua essência, a forma de compararmos humanos aos macacos já nos torna relevantemente desinformados.

James Bradley professor de História da Medicina/Ciência da vida da University de Melbourne na Austrália em um dos seus textos "The ape insult: a short history of a racist Idea" $(\mathrm{O}$

macaco como insulto: uma curta história de uma idéia racista), detalha o uso ofensivo da comparação de descendentes de africanos com o animal macaco e cita:"Claramente, o sistema educacional não faz o suficiente para nos educar sobre a ciência ou a história do 
homem. Porque se o fizesse, nós veríamos o desaparecimento do uso do macaco como insulto."

Comparar negros e macacos força essa perversidade da história, tendo o racismo presente desde o início do séc. XVIII. A comparação do eurocentrismo com as desigualdades das populações, os escravos não possuíam almas, assim como os índios, é voltar a venerar os episódios, as piadas, o humor na mídia, os tão conhecidos Stand-up, comédias que as pessoas tanto adoram, riem de negros, pobres, desdentados entre outros, ou seja, o que há de pior no ser humano o "preconceito".

O racismo ou qualquer tipo de discriminação ou qualquer tipo de agressão ofensiva deve ser punido a fim de se valorizar o ser humano e fazer se reconhecer, como uns descendentes dos outros e como seres iguais, não importando a cor da pele, ideologia e política .

O mundo carece de pessoas que fazem a diferença como Nelson Mandela, Martin Luther King dentre outros da nossa história, uns que morreram lutando infelizmente, outros presos injustamente.

Acredita-se que para evoluir não basta criar meios tecnológicos, pois até mesmo os povos paleolíticos, nossos antecedentes, criaram o fogo, outros a roda, ainda tivemos Albert Einstein o maior físico da história que disse: “Triste época! É mais fácil desintegrar um átomo do que um preconceito", ou uma frase de Nietzsche: "Humanos demasiadamente humanos".

Assim, deve-se pautar, na compreensão de que vive-se em sociedade, e tem-se o fim comum, que une a humanidade, que uma sociedade harmônica. Para isso, deve-se ter alteridade, e nos apropriarmos definitivamente da igualdade que há entre todos, do dever do respeito ante a diversidade. Neste sentido, apregoa Boaventura de Sousa Santos que "Temos o direito de ser iguais quando a nossa diferença nos inferioriza; e temos o direito de ser diferentes quando a nossa igualdade nos descaracteriza. Daí a necessidade de uma igualdade que reconheça as diferenças e de uma diferença que não produza, alimente ou reproduza as desigualdades"(2003, p. 56). 


\section{Considerações Finais}

Conclui-se que falar de teoria não é algo que simplesmente foi inventado, elaborado da mente em um único momento e sim ao ponto de vista de religiosos que perduraram por séculos perseguindo cientistas e queimado na fogueira da ignorância seus medos e receios de ser retirada sua tese, sua crença.

A teoria é como dizer que somos um país da América do Sul e ponto final. Pois somos! O que mudar se a ciência vem e prova?

Darwin sofreu perseguições devido a "perigosa ideia de Darwin", como a apelidou o filósofo americano Daniel Dennett, também pôs em dúvida outro conceito importante para muitas religiões: o suposto status especial do homem perante os demais seres vivos.

Essa ruptura radical chocou os religiosos que no primeiro momento fez Darwin sofrer perseguições, mudou o rumo global, física, cosmológica, biológica, bioquímica, antropológica e acima de tudo a teoria do conhecimento, levando ao fim a metafísica criada por Aristóteles e a antropologia espiritual. Passamos por assim dizer do estático de Parmênides ao movimento de Heráclito.

Trata-se de uma vida terrena e material que se desenvolveu e se sustenta por si só sem plano desconhecido. O sentido de evolução atinge a humanidade e toda compreensão, a cultura, comportamento passa a ser autentico, não que o religioso deixe de ser importante, mas saber que as espécies evoluem cientificamente, podendo com isso atribuir analises minuciosas tanto do Universo e os modelos evolutivos dos cosmos e matéria.

A humanidade passou por grandes períodos, os processos históricos expostos nesse artigo apresenta a visão das questões que foram cientificamente analisadas, pelos religiosos, por ateus entre outros, a humanidade passa por esse processo histórico sendo unificado pela era cristã dividindo a história em a.C e d.C (antes e depois de Cristo).

Assim a identidade européia foi construída de tal base que veio trazendo as questões eurocêntricas para outros povos e suas regras de dominar e doutrinar e de todos serem modelos "iguais" como originados de "fôrmas". 
Podemos observar que tanto as civilizações antigas, quanto os povos ditos "civilizados" e a subjugação do dos índios como os "bons selvagens, mudou a estrutura de forma de pensar, de acordo com a necessidade dos dominadores e de seus interesses materiais.

Posteriormente, o que sobrou foram 400 anos de escravidão e opressão aos negros vindos da África, de onde também os europeus viram os macacos e fizeram a comparação lamentável

sobre as aparências, fato esse lamentável e que reflete diretamente nas pessoas negras, em pleno século XXI, independente de classe social, em todas as esferas.

$\mathrm{O}$ negro era proibido, até o início do século $\mathrm{XX}$, de ser padre entre outras formas de preconceito, com o caso do jogador conhecido por Carlos Alberto, que em 1914, no time Fluminense do Rio, pintou seu rosto com pó de arroz, para conseguir jogar, pelo fato de não se aceitar negro no time.

As questões raciais americana perduraram até 1963 quando Martin Luther King herói da luta contra a segregação racial dita a famosa frase: "I have dream." Este sonho perdura em nós até hoje, que seja o mundo um lugar onde possamos viver todos em paz.

Precisa-se de respeito, amor e não discriminação.A cada 25 minutos um negro entre a idade de 13 a 27 anos é assassinado no Brasil, são dados registrados junto a Secretaria de Direitos Humanos da Presidência da República. A quem interessa saber se alguém foi morto ou hostilizado em um campo de futebol? Será normal chamar um negro de macaco? Está enraigado na sociedade? Ou é uma maneira de se esquecer que somos descendentes dos negros.Nossa história é evolutiva e que todos os seres vivos são primos.

Cada espécie é uma, descendemos de uma evolução, as pesquisas científicas afirmam que somos parentes próximos, mas não somos espécie de grande primata, não somos macacos, somos humanos...e movimentos como o \#somos todos macacos\# é um equívoco, que pode gerar não a defesa dos direitos e a não discriminação, mas a continuidade da associação entre homem e macaco, é a continuidade de uma discriminação cruel, em que se coloca a pessoa humana negra numa condição rebaixada da humanidade, e isto é inadmissível! 


\section{REFERÊNCIAS}

ABBAGNANO, Nicola. Dicionário de Filosofia. tradução Ivonne Castilho Benedetti; São Paulo: Martins Fontes, 2007.

BÍBLIA. Bíblia de Jerusalém. São Paulo: Paulus, 2002.

DAWKINS, Richard. A grande história da evolução: na trilha dos nossos ancestrais;

tradução Laura Teixeira Motta. São Paulo: Companhia das Letras, 2009.

A magia da realidade: como sabemos o que é verdade; tradução Laura Teixeira Motta. São Paulo: Companhia das Letras, 2012.

Deus um delírio. tradução de Fernanda Ravagnani. São Paulo: Companhia das Letras; 2007.

O Gene Egoísta; tradução de Rejane Rubino. São Paulo: Companhia das Letras, 2007.

DARWIN, Charles. A Origem das espécies; tradução Carlos Duarte e Anna Duarte. São Paulo: Martin Claret, 2014.

SANTOS, Boaventura de Sousa. Direitos Humanos: o desafio da interculturalidade. Junho

2009, vol. $\quad 02 \quad$. $\quad 02$ Disponível em:< http://www.boaventuradesousasantos.pt/media/Direitos\%20Humanos_Revista\%20Direitos $\% 2$ 0Humanos2009.pdf>. Acesso em 12 de abril de 2015

multicultural.

Reconhecer para libertar: os caminhos do cosmopolitanismo

Introdução: para ampliar o cânone do reconhecimento, da diferença e da igualdade. Rio de Janeiro: Civilização Brasileira, 2003. 